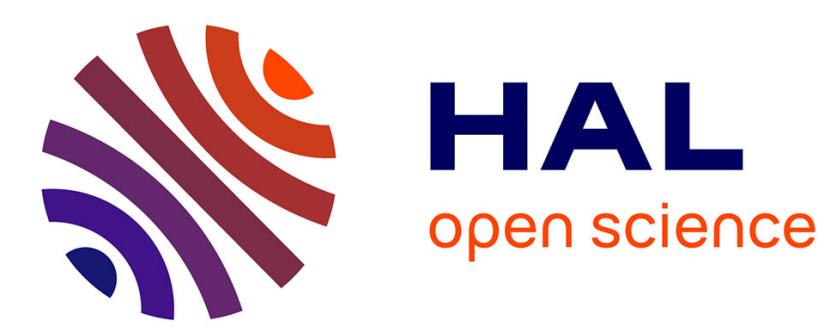

\title{
Separated by a common translation? How the British and the Dutch communicate
}

\author{
Bart Louis Rottier, Nannette Ripmeester, Andrew Bush
}

\section{To cite this version:}

Bart Louis Rottier, Nannette Ripmeester, Andrew Bush. Separated by a common translation? How the British and the Dutch communicate. Pediatric Pulmonology, 2010, 46 (4), pp.409. 10.1002/ppul.21380 . hal-00604881

\section{HAL Id: hal-00604881 \\ https://hal.science/hal-00604881}

Submitted on 30 Jun 2011

HAL is a multi-disciplinary open access archive for the deposit and dissemination of scientific research documents, whether they are published or not. The documents may come from teaching and research institutions in France or abroad, or from public or private research centers.
L'archive ouverte pluridisciplinaire HAL, est destinée au dépôt et à la diffusion de documents scientifiques de niveau recherche, publiés ou non, émanant des établissements d'enseignement et de recherche français ou étrangers, des laboratoires publics ou privés. 


\section{Separated by a common translation? How the British and the Dutch communicate}

\begin{tabular}{|c|c|}
\hline Journal: & Pediatric Pulmonology \\
\hline Manuscript ID: & PPUL-10-0382 \\
\hline Wiley - Manuscript type: & Original Article \\
\hline $\begin{array}{r}\text { Date Submitted by the } \\
\text { Author: }\end{array}$ & 22-Oct-2010 \\
\hline Complete List of Authors: & $\begin{array}{l}\text { Rottier, Bart; University Medical Center Groningen, Pediatric } \\
\text { Pulmonology } \\
\text { Ripmeester, Nannette; Expertise in labour mobility } \\
\text { Bush, Andrew; Imperial School of Medicine at National Heart and } \\
\text { Lung Institute }\end{array}$ \\
\hline Keywords: & communication, review, cooperation \\
\hline
\end{tabular}

\section{SCHOLARONE $^{\text {TM }}$ Manuscripts}


1

2

3

\section{Separated by a common translation? How the British and the Dutch}

$$
\text { communicate }
$$

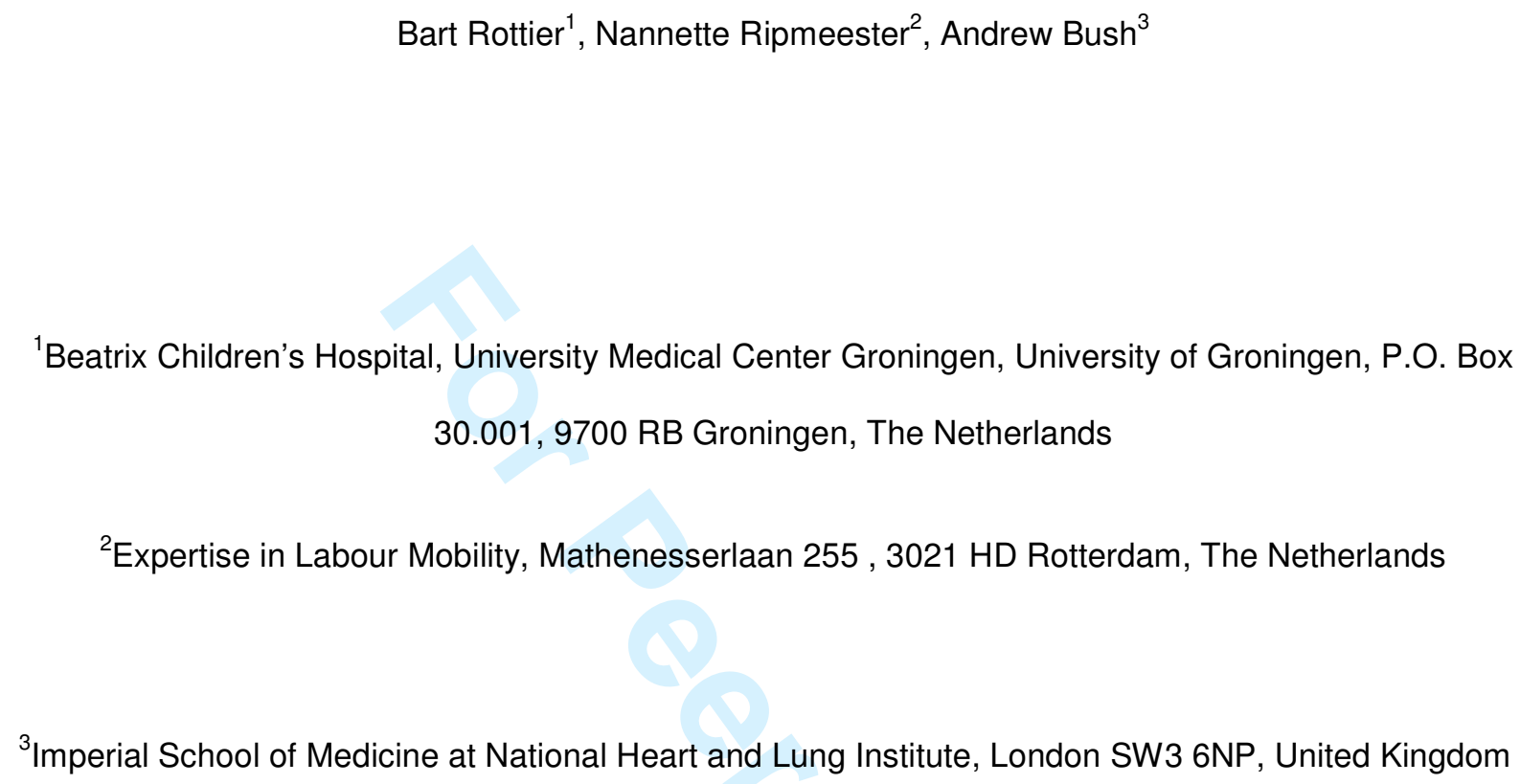
30.001, 9700 RB Groningen, The Netherlands

${ }^{2}$ Expertise in Labour Mobility, Mathenesserlaan 255 , 3021 HD Rotterdam, The Netherlands

${ }^{3}$ Imperial School of Medicine at National Heart and Lung Institute, London SW3 6NP, United Kingdom

No conflicts or interest to declare

No funding and no study sponsors

Key words: communication, review, cooperation

Corresponding author: b.l.rottier@bkk.umcg.nl

Abbreviated title: British-Dutch communication 


\begin{abstract}
The British and Dutch share a long naval-, war- and medical history, in good times as well as bad. Their language has a common Germanic origin, but the English people may use special ways to express values or opinions, from which the sometimes paradoxical meaning is not always clear to the other party. Particularly with the Dutch, renowned for their directness, this may cause confusion. We provide a comprehensive set of expressions, each with paired interpretations, to foster Anglo-Dutch cooperation.
\end{abstract}




\section{Introduction}

The British and Dutch share a long history, in good times as well as bad. In the Anglo-Dutch wars, Michiel Adriaenszoon de Ruyter played a major role as a skilled Dutch admiral as did his famous British counterpart Admiral Robert Blake. Nowadays the Royal Navy and Royal Dutch Navy still cooperate together at high level in the Flag Officer Sea Training. Our health systems differ, but also share common ground: the Dutch equivalent of the National Health Service is a compulsory health insurance system for everyone. British and Dutch doctors meet in conference and on other occasions; scientific articles are written together and reviewed by both nationalities. Medical care is strongly influenced by centuries of development of cultural beliefs and ideas, as has been beautifully written up by (the deceased) Lynn Payer. ${ }^{1}$ Differences between the two nations exist in many areas, although for the outside world the Dutch and the British seems to get along quite well. Despite the differences in the success or otherwise of their respective football teams ${ }^{2}$, the Dutch and British have a lot in common besides the weather. The medical communities of both countries have a significant profile in preclinical and clinical research. Language- and cultural differences may play an important role at conferences and in the process of submitting and reviewing articles.

The aim of this article is to improve mutual understanding during these professional and social encounters as well as in the writing and reviewing process of scientific articles. We hope to show that the provision of a comprehensive set of expressions, each with paired interpretations, fosters AngloDutch cooperation.

\section{Materials and methods}

In-depth interviews with Dutch expats and their British employers on common expressions and their meanings resulted in "misunderstandings" that were checked and cross checked for meaning and interpretation. In the following years these expressions have been tested on multiple occasions. Editorial comments and those of reviewers of medical scientific articles were picked out by the authors on the basis of suspected paradoxical meaning and discussed among the authors.

\section{Results}

The results from the in-depth interviews and reviewers and editorial comments are posted in tables with the expression itself, it's meaning and how it might be understood by non-Britsh citizens. Although 
we share a rich history and ideas, there are nevertheless often cases where the communication between the two nations is not as straight forward as might be expected. This is clear from reading table 1 and table 2 for social encounters and the reviewing process respectively.

\section{Discussion}

From these study results is it is clear that the British use of language often causes confusion among the other nationalities. English people may use special ways to express values or opinions, from which the sometimes paradoxical meaning is not always clear to the other party. Particularly with the Dutch, renowned for their directness, this may cause confusion.

We hypothesize that the differences may well have their origin in the gentlemanlike, polite nature of the British (according to the Dutch authors) or their utter dishonesty (the British version). It has been shown that British gentleman-like behavior is often even maintained in disastrous circumstances such as the sinking of the Titanic (April $15^{\text {th }} 1912$ ), where British nationality overall (corrected for class of travel) resulted in lower probability of survival ( $\mathrm{p} 0.01$ ) compared to other European nationalities and US citizens. ${ }^{3}$ Time is of importance however, and a more slowly sinking ship may lead to a different view: the Titanic sank in $2 \mathrm{~h} 40 \mathrm{~min}$, the Lusitania in just $18 \mathrm{~min}$; the latter leading to more selfish behaviour. $^{4}$

This guide may helpful not just to British and Dutch medical doctors, but also to native speakers from other European languages and even those using American-English or Australian-English. Both Dutch and English have developed from the Germanic languages. ${ }^{5}$ This can be illustrated by the conjugation of verbs (present/past/past participle): "eten/at/gegeten" and "to eat/ate/eaten". Nevertheless, the possibilities for misunderstandings are numerous, as we show in table 1 for social encounters, and in table 2 for the scientific review environment. As a rule of thumb, most Dutch people are less used to playing with the language as the British. This contrasts with the much greater levels of Dutch footballing schools. ${ }^{2}$ Both may be just as true for German, Spanish and other European nationalities. However, eloquence on the football field and in the use of language seem to be two different things. This guide should at least help people to get to grips with the latter. The former we will leave for another year when we can all talk about football again without the relative recent memory of a world cup. 


\section{Background and contributions:}

Prof A. Bush is the 2008 Jonxis medallist; his prize lecture 'Asthma: Problematic, Difficult, and Therapy Resistant - the Brompton experience' in 2008' was completely eclipsed by BR's presentation of some of these ideas. NR developed table 1 of the translation guide on the basis of her work with Dutch expats ${ }^{6}$. BR has tested elements of this translation guide on different occasions with British medical doctors, which always resulted in a good laugh as it is generally believed to reflect the truth. The naval inspiration results from fulfilling the military service as a ships doctor for the Royal Dutch Navy, where Dutch and British doctors did get along well. AB added even more intercultural flavour to the translation guide and reviewed the English. The reference to football was initiated by the World Cup tournament in July 2010.

\section{References}

${ }^{1}$ Lynn Payer. Medicin and Culture, Varieties of Treatment in the United States, England, West Germany and France; 1988 ISBN 0140124047

${ }^{2}$ http://www.fifa.com/worldfootball/ranking/lastranking/gender=m/fullranking.html accessed at july 14 th 2010

${ }^{3}$ Frey BS, Savage DA, Torgler B. Noblesse Oblige. Determinants of survival in a life and death situation. Working paper series 2425 (2008), ISSN 1424-0459

${ }^{4}$ Frey BS, Interaction of natural survival instincts and internalized social norms exploring the Titanic and Lusitania disasters, www.pnas.org/cgi/doi/10.1073/pnas.0911303107 ${ }^{5}$ http://en.wikipedia.org/wiki/English language.

${ }^{6}$ Nannette Ripmeester. Looking for work in the United Kingdom; 1997 ISBN 978-90-5896-059-7. 
Table 1: translation guide social

\begin{tabular}{|c|c|c|}
\hline What the British say & What the British mean & What the Dutch understand \\
\hline I hear what you say & I disagree completely & $\mathrm{He}^{*}$ accepts my point of view \\
\hline $\begin{array}{l}\text { You must come by for dinner } \\
\text { sometime }\end{array}$ & Just being polite; Goodbye! & $\begin{array}{l}\text { He will invite me for dinner in } \\
\text { the course of time }\end{array}$ \\
\hline Very interesting & I don't agree & He likes my idea \\
\hline With the greatest respect & You must be a fool & He respects me/my view \\
\hline I'm sure it's my fault & It's your fault! & It is his fault \\
\hline That is an original point of view & You must be crazy & They like the idea \\
\hline I almost agree & I don't agree & He almost agrees \\
\hline You'll get there (eventually) & No way you will make it & Encouragement to go on \\
\hline I'll bear it in mind & I won't do anything about it & He will use it when appropriate \\
\hline $\begin{array}{l}\text { Could we consider some other } \\
\text { options }\end{array}$ & I don't like your idea & $\begin{array}{l}\text { He is still in the process of } \\
\text { thinking }\end{array}$ \\
\hline I would suggest & Do it as I want you to & An open suggestion \\
\hline By the way & The primary purpose is & Not very important \\
\hline $\begin{array}{l}\text { Perhaps you could give this } \\
\text { some more thought }\end{array}$ & Don't do it, it's a bad idea & Consider possible road blocks \\
\hline Quite good & A bit disappointing & Quite good \\
\hline Not bad & (very) good & Average or poor \\
\hline
\end{tabular}




\section{Table 2: Translation guide: professional (review process)}

What the British write

Please consider
I have a further suggestion
The method described is rather
original
I have a few preliminary
suggestions
Reads well
I am somewhat disturbed by the
methodology

With all due respect

A few issues that need to be addressed

\section{An issue that worries me} slightly

I am sorry we have to reject your paper on priority grounds

I am sorry to disappoint you on this occasion

* Where "he" is mentioned "she" can also be read disagreement) changed

\section{What the Dutch read}

He* leaves it up to me

He leaves it up to me

It's a good method

Don't change anything until

final suggestions have been

made

\section{Average}

He is not feeling too

comfortable about it

With the greatest respect doing, I have a better suggestion (polite

\section{A whole lot needs to be}

2-3 issues need rewriting

A great worry

Your paper sucks

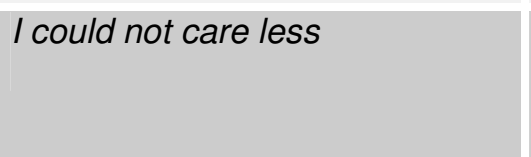

My paper nearly made it

He is sorry

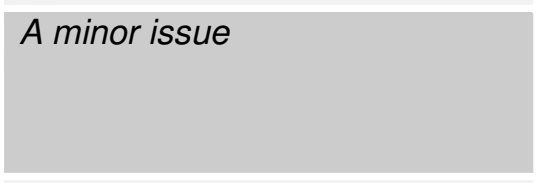

